\title{
Analysis of electromagnetic fields in transmission line configurations associated with the electrical system
}

\author{
Adrian Beria \\ adrberia@hotmail.com \\ https://orcid.org/0000-0003-0080-1708 \\ UNEXPO Puerto Ordaz \\ Edo. Bolívar, Venezuela
}

\author{
Juan Toledo \\ Toledo.juan@gmail.com \\ https://orcid.org/0000-0002-0327-3050 \\ CORPOELEC \\ Edo. Bolívar, Venezuela
}

Received (16/04/21), Accepted(04/05/21)

\begin{abstract}
Thisworkpresents an analysis of the electromagneticfields generated bythe different configurations of transmission lines associated with the Venezuelan electrical system, with voltages 230,400 and 765 kilo Volts, and the transmission towers that will be built at the Manuel Piar Hydroelectric Plant. -Tocoma. The theoretical aspects and technical foundations for the evaluation of the magnetic field in transmission lines are analyzed. The work was carried out at the CORPOELEC company in Venezuela. The criteria and technical regulations were observed to verify respect for the levels allowed by national and international standards, to which a person may be exposed. The results show the location areas of the transmission lines and their corresponding electromagnetic analysis.
\end{abstract}

Keywords: Electromagnetic fields, transmission lines, transmission towers.

\section{Análisis de los campos electromagnéticos en las configuraciones de líneas de transmisión asociadas al sistema eléctrico}

\begin{abstract}
Resumen: En este trabajo se presenta un análisis de los campos electromagnéticos generados por las diferentes configuraciones de líneas de transmisión asociados al sistema eléctrico venezolano, de tensiones 230, 400 y 765 kilo Voltios, y las torres de transmisión que se construirán en la Central Hidroeléctrica Manuel Piar- Tocoma. Se analizan los aspectos teóricos y los fundamentos técnicos para la evaluación del campo magnético en las líneas de transmisión. El trabajo se realizó en la empresa CORPOELEC en Venezuela. Se observaron los criterios y normativas técnicas, para constatar el respeto por los niveles permitidos por las normas nacionales e internacionales, a los cuales puede estar expuesta una persona. Los resultados muestran las zonas de ubicación de las líneas de transmisión y su correspondiente análisis electromagnético.
\end{abstract}

Palabras Clave: Campos Electromagnéticos, Líneas de transmisión, torres de transmisión.

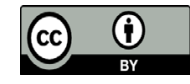




\section{I.INTRODUCTION}

In Venezuela, most of the electricity is generated in hydroelectric power plants, which are responsible for transforming the potential energy of the river in the reservoir, the kinetic energy produced by the movement of water through the gates, and the mechanical energy produced by the movement of the rotor, into electrical energy. It is transported through transmission lines, with voltage levels of 230, 400, and 765 kiloVolts $(\mathrm{kV})$.

During this process, large amounts of current and voltages are transported, which generate high intensity magnetic and electric fields respectively, which through the ANSI C37-32-1996, NEMA SG-6-1995, COVENIN 2238:2000 standards, and the national safety code for electrical power supply and communications facilities [2-5], have defined the minimum levels to which a person can be exposed without running risks.

This work presents a study of the electromagnetic fields generated by the different configurations of CORPOELEC transmission lines, using a simple methodology that will allow us to calculate the magnetic or electric field of any desired configuration and to see the levels to which people are exposed under those lines.

For this purpose, the electrical characteristics of the line will be analyzed, such as voltage, current, apparent power, magnetic permeability, electrical permittivity, angular frequency, yielding the results of the field levels produced by the conductors, the distribution in the environment of the field lines, and finally a comparison between the different transmission lines and their location by zones.

The Manuel Piar (Tocoma) hydroelectric power plant is located on the Caroní River, upstream from the mouth of the Claro river, between the municipalities of Angostura and Piar, approximately $18 \mathrm{~km}$ downstream from the Simón Bolívar (Gurí) hydroelectric power plant in the state of Bolívar, Venezuela.

The Tocoma development will form, together with the Gurí, Macagua, and Caruachi hydroelectric plants, the lower Caroní hydroelectric system. The outstanding energy characteristics of the project are predetermined by the regulated discharge of the Guri Project, which will contribute together with the other hydroelectric plants, contributing 2,160 MW to the national interconnected system.

The hydroelectric power plant is made up of several concrete structures, being a Power House integrated into the Intake structure and Assembly Building, with ten (10) Kaplan-type turbine units and a total installed capacity of 2,160 MW. 160 MW, a Lateral Services Building, an Operations and Control Building, left, right and intermediate transition dams, a spillway with nine (9) radial gates and eighteen (18) bottom ducts, a rockfill dam with a concrete screen on he left bank and an earth and rockfill dam with clay core on the right bank.

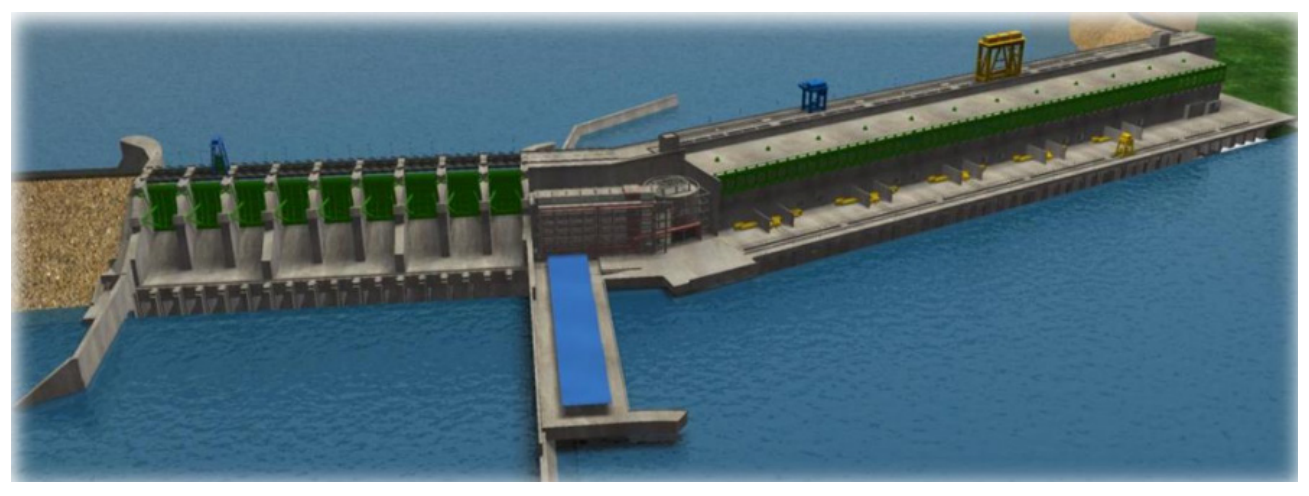

Fig.1. Future three-dimensional model of the Manuel Piar-Tocoma hydroelectric power plant.

Five (5) towers with two conductors per phase and two guard cables will be used, with horizontal arrangement of the phases, A50/CAR type towers facing Tocoma S/E, as shown in Figure 2. 


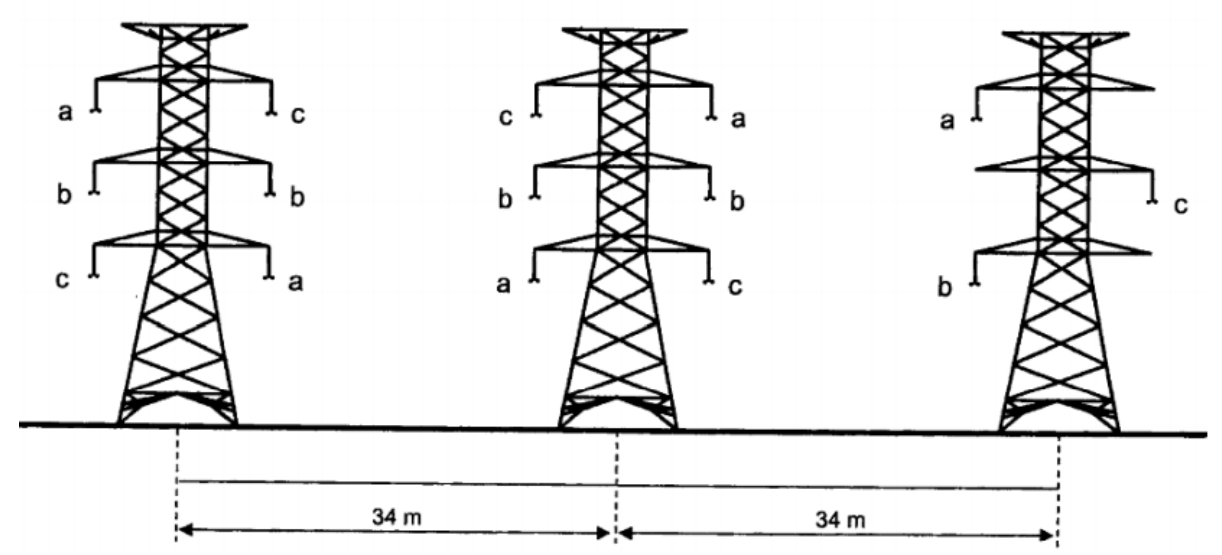

Fig. 2. Recommended tower spacing distance and phase arrangement. Lines between the plant and the Tocoma substation at $400 \mathrm{kV}$.

In that path, transmission lines generate electric and magnetic fields at an industrial frequency of $60 \mathrm{~Hz}$. These play an important role in the design and operation of transmission lines. The study of electric fields in these structures is important in terms of current induction in conductive materials in general, such as vehicles, the transmission tower itself, electrocutions caused by spark discharges, interference with pacemakers, and electric arcs [1]. While magnetic fields, due to the inductive effect on parallel lines and interference with computer screen operation [2].

\section{II.DEVELOPMENT}

The objective of this work is to analyze the Electromagnetic Fields generated by the different configurations of transmission lines most used in the Venezuelan National Electric System with special attention to the Manuel Piar Tocoma Hydroelectric Power Plant.

Electricity and magnetism are two different aspects of the same physical phenomenon, called electromagnetism [8], [9]. This theory unifies the electric and magnetic phenomena in one, whose foundations are due to Faraday, but was formulated in a more general form by Maxwell. The formulation consists of four-vector differential equations, known as Maxwell's equations, which relate the electric field, the magnetic field, and their respective material sources: electric charge density, electric current, electric displacement, and displacement current [8].

James Clerk Maxwell [12], based on Faraday's work but modifying some concepts and interpretations, mathematically structures the electromagnetic theory and introduces the displacement current. He proves directly that the fields fulfill a wave equation where the phase velocity coincides with the speed of light. The electromagnetic character of light was demonstrated by Hertz, with his experiments on the propagation of electromagnetic waves in 1887, and by Zeeman in 1896 when he showed that there were charges capable of moving with sufficient acceleration to radiate within the visible spectrum.

The now called Maxwell's equations demonstrated that electric fields and magnetic fields were manifestations of a single electromagnetic field. The motion of an electric charge produces a magnetic field, the variation of a magnetic field produces an electric field, and the accelerated motion of electric charges generates electromagnetic waves.

Nikola Tesla [13] is best known for his many revolutionary inventions in the field of electromagnetism, developed in the late 19th and early 20th centuries. Tesla's patents and theoretical work formed the basis of modern alternating current (AC) electrical power systems, including the polyphase electrical distribution system and the AC motor, which contributed so much to the birth of the Second Industrial Revolution.

Since Nikola Tesla [13] discovered alternating current and the way to produce it in alternators, an immense technological activity has been carried out to bring electricity to all inhabited places in the world, so that, along with the construction of large and varied power plants, sophisticated transmission networks and distribution systems have been built. Most of the electricity generated worldwide comes from the first three types of power plants: thermal, hydroelectric, and wind.

The transportation networks of the generated electric energy are made through transmission lines as a first pha- 
se. However, these entail several problems, among the most important, the environmental impacts and their effect on people's health, the latter has been of great concern and has been the subject of study for decades, however many studies conclude that "there is still no relationship between the presence of electric and magnetic fields with cancer or other diseases affecting human beings", according to the book Electromagnetic Fields and Human Health, by John E. Moulder, professor of oncology at the University of California, Berkeley, USA. Moulder, professor of radiation oncology at the Medical College of Wisconsin, USA, contains the most frequently asked questions and answers on the subject, as well as a bibliography of research studies on power lines and health around the world.

The study of electromagnetic fields in transmission lines is nowadays a subject of great interest for the world, countries like Lebanon have made detailed studies on the numerical calculation of these fields using the multipole expansion theory, as they did:

Some research [9] developed a detailed analysis of the magnetic fields emitted by $220 \mathrm{kV}$ transmission lines in Lebanon. An overview of the latest developments in transmission line designs is made, including recent configurations and different conductor locations to help reduce the emitted magnetic field and making a basic review of the equations governing the magnetic field to be used later. There is also a worldwide investigation done by various studies discussing the health impact of ultra-high voltage lines. Concluding with analysis, using software that makes use of the Finite Element Method to estimate the magnetic field of transmission lines [10].

Some authors [11] present a model of electric and magnetic fields in transmission systems, which operates through a partial differential equation. This research has been conducted by analyzing the electromagnetic fields radiating around transmission lines, which uses line transposition in case of long distributions. The six (6) types of $500 \mathrm{kV}$ transposed transmission line configurations with double circuits will be considered.

\section{III.METHODOLOGY}

The different transmission line configurations associated with the Venezuelan National Electric System will be analyzed. The technical data of each configuration to be studied will be used to generate the magnetic and electric field graphs.

First, the analysis will be performed on two $400 \mathrm{kV}$ transmission lines, the first one is an A50/CAR type tower, with two ALUMOWELD $7 \# 6$ guard wires, a circuit with three phases, together with two conductors per phase (2 $\mathrm{x} 1024.5 \mathrm{MCM})$. And the other is an A/55/TT/222 tower, two conductors per phase, double circuit, using the same types of conductors. These models are the ones that will be used in the Manuel Piar hydroelectric power plant, three towers A/55/TT/222, or double circuit, will be used to connect each output of the transformers to a circuit, but the last tower will use an equivalent delta distribution, connecting with five transmission towers $\mathrm{A} / 50 / \mathrm{CAR}$ before reaching the S/E Tocoma.

\section{A.Data collection techniques and instruments.}

Then, the fields generated by the 765,400 and $230 \mathrm{kV}$ transmission line configurations will be studied.

To carry out this research, the following tools were used for data collection:

-Google Chrome, the internet browser used for the research, which allowed obtaining the international standards that indicate the maximum level of electromagnetic fields to which a person can be exposed.

-CORPOELEC's Intranet, which allowed obtaining the electrical data of each transmission line configuration of the company used in the Venezuelan National Electric System.

-CVG EDELCA's plans and manuals, which includes the transmission line models, along with the measurements of the towers, guard cables, conductors and insulators, which allowed the creation of the physical model.

-MATLAB, the program in which the plots of the electromagnetic fields generated in the transmission line configurations were made.

-ANSYS, the program in which the results obtained by the MATLAB software were validated.

\section{IV.RESULTS}

The advantages offered by computers in numerical calculations have allowed the development of programs with a high degree of accuracy, in this case, MATLAB will be used, which through the exposed methodology will 
proceed through an algorithm to simulate the electromagnetic fields generated by the different configurations of transmission lines associated with the Venezuelan electrical system.

The maximum level of the electric and magnetic field to which a person can be exposed is $4.16 \mathrm{kV} / \mathrm{m}$ and 83.3 $\mathrm{A} / \mathrm{m}$, respectively, generally in the transmission lines there are high levels near the conductors, however, the field decreases the farther away it is from the source, that is why two types of results are analyzed, the first is a graphical view of the fields generated in the conductors, then a two-dimensional graph of the field levels to the transverse distance to the lines, which shows the exposure to the fields of people of an average height of 1.75 meters, which are located just below the lines.

The National Electric System is made up of 18 public and private electric companies. The private companies are Electricidad de Caracas and its subsidiaries. The companies CADAFE, EDELCA, E. de C., and ENELVEN, signatories of the Interconnection Contract, supply $95.4 \%$ of the electric energy consumed in the country, and these, in turn, represent in OPSIS the total value of the aforementioned electric companies. The remaining percentage comes from the Self-supplied Sector (Petróleos de Venezuela, independent producers, and industries with their generation). Figure 3, highlights part of the national interconnected system.

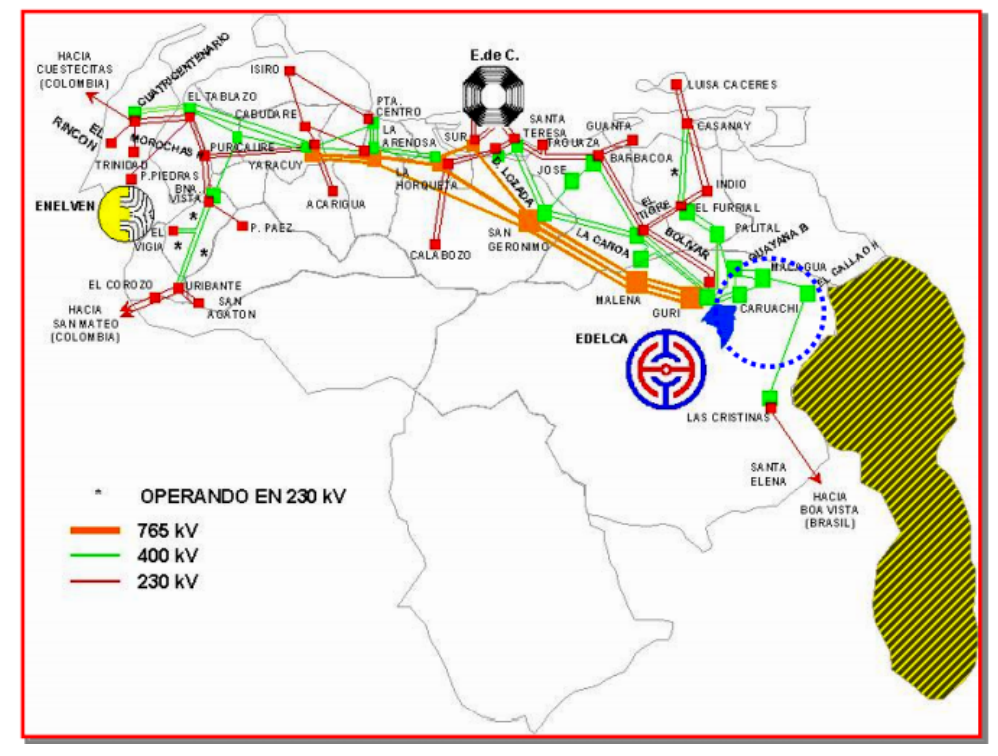

Fig. 3. National electric system, Venezuela.

At $765 \mathrm{kV}$ voltage levels, the highest levels of electromagnetic fields are produced, because it is the line that transmits the highest voltage and current, therefore, magnitudes of high electric and magnetic fields compared to the others. The following table shows the location and lines current of each of the configurations for this voltage level.

The current level is the same in each of the lines, although in each sub conductor 1695.75 Amperes are handled because they are horizontal towers of four conductors per phase, this means that the level of electromagnetic fields is the same in each area where the $765 \mathrm{kV}$ lines are located, however in some areas, different heights are producing different levels of the field on the ground, this is because the higher the height of the conductors to the ground, the lower the effect will be. The graphical results generated in the line configurations of these zones are located in section A-3.

For transmission, $400 \mathrm{kV}$ is usually used as the output of hydroelectric power plants such as Macagua, Caruachi, Tocoma, and some lines of Gurí. In this case, there is a greater variety of line configurations, horizontal with two conductors per phase, a double circuit with two and four conductors per phase, and 77 different current levels generating magnetic fields of various magnitudes (Table 2). 
Table 1. Location and current levels of $765 \mathrm{kV}$ transmission lines.

\begin{tabular}{|c|c|c|c|c|}
\hline \multicolumn{2}{|c|}{ Líneas } & \multirow{2}{*}{\begin{tabular}{c} 
Nivel de \\
Corriente \\
\cline { 5 - 5 }
\end{tabular}} & Barra Final & \multirow{2}{*}{ Alturas de los conductores } \\
\cline { 5 - 5 } & & Mínima & Máxima \\
\hline Gurí & Malena & 6783 & 15 & 43.70 \\
\hline Malena & San Gerónimo & 6783 & 15 & 43.70 \\
\hline San Gerónimo & Horqueta & 6783 & 15 & 43.70 \\
\hline San Gerónimo & Sur & 6783 & 13.2 & 43.00 \\
\hline San Gerónimo & Arenosa & 6783 & 15 & 43.70 \\
\hline Arenosa & Yaracuy & 6783 & 13.2 & 43.00 \\
\hline Horqueta & Arenosa & 6783 & 13.2 & 43.00 \\
\hline Horqueta & Sur & 6783 & 13.2 & 43.00 \\
\hline
\end{tabular}

In many areas the same $400 \mathrm{kV}$ line configurations are repeated, based on this, there are fourteen different types, which present a great variety of electromagnetic fields, both in distribution and magnitude, having cases where there are very low levels, such as the case of Tablazo-Cuatricentenario line 2, as well as others where there are large magnitudes such as the Gurí-Palital lines. The graphic results generated in the line configurations of these zones are located in section A-4.

Table 2. Location and current levels of the main $400 \mathrm{kV}$ transmission lines.

\begin{tabular}{|c|c|c|c|c|}
\hline \multicolumn{2}{|c|}{ Líneas } & \multirow{2}{*}{$\begin{array}{l}\text { Nivel de } \\
\text { Corriente } \\
\text { (Ampere) }\end{array}$} & \multicolumn{2}{|c|}{$\begin{array}{l}\text { Alturas de los } \\
\text { conductores }\end{array}$} \\
\hline Barra Inicial & Barra Final & & Mínima & Máxima \\
\hline Gurí & Tigre L1 & 3127.5 & 8 & 16.74 \\
\hline Gurí & Tigre L2 & 3062.5 & 8 & 22.50 \\
\hline Gurí & Canoa & 3062.5 & 8 & 27.00 \\
\hline Canoa & Tigre & 3062.5 & 8 & 27.00 \\
\hline Tigre & San Gerónimo L1 & 3127.5 & 8 & 16.74 \\
\hline Tigre & San Gerónimo L2 & 3062.5 & 8 & 22.50 \\
\hline San Gerónimo & Santa Teresa L1 & 3127.5 & 8 & 16.74 \\
\hline San Gerónimo & Santa Teresa L2 & 3062.5 & 8 & 22.50 \\
\hline Tigre & Barbacoa II & 3062.5 & 8 & 27.00 \\
\hline José & Barbacoa II & 3062.5 & 8 & 26.00 \\
\hline San Gerónimo & José & 3062.5 & 8 & 26.00 \\
\hline Gurí & Guayana B L2 y L3 & 6125.0 & 7.6 & 26 \\
\hline
\end{tabular}


In $230 \mathrm{kV}$ lines, there are lower voltage and current levels, generating consequently lower electric and magnetic fields, however, an important factor concerning other configurations is the number of sub conductors per phase.

In this case, it is one conductor per phase, this is relevant because the double circuit towers, which present greater distribution of fields in the zones, present lower levels of electric and magnetic fields, because the equipotential lines are reduced.

In the delta configuration, there is a lower magnitude and field distribution in the zone where they are located.

\section{IV.CONCLUSIONS}

If there are areas where the electromagnetic field level is higher than allowed by the standards, it is recommended to use field mitigation methods. In a study done [23] a theoretical and experimental study was made of the mitigation of the magnetic fields generated in a model of high voltage lines employing a passive loop or closed loop, of non-energized conductors, to which a current is induced in the opposite direction to that of the lines, generating a field opposite to the original one, reducing the total field.

It is advisable to perform these simulations in the MATLAB program because ANSYS requires machines with a high graphic processor and the designed algorithms yield very accurate results, concerning the program used to validate.

It is recommended to continue this research to study electromagnetic fields in substations, produced during electrical faults such as single-phase, two-phase, and three-phase, where there are high levels of short circuit current generating very high field magnitudes, which could cause interference with measuring equipment and exceed the minimum level of electromagnetism to which a person can be exposed.

\section{REFERENCES}

[1]EPRI AC Transmission Line Reference Book- $200 \mathrm{kV}$ and Above, Third Edition. 2005

[2]"Interruptores de desconexión de aire de alto voltaje estándar nacional estadounidense Interruptores interruptores, interruptores de iniciación de fallas, interruptores de puesta a tierra, soportes de bus y accesorios Rangos de voltaje de control: programas de clasificaciones preferidas, pautas y especificaciones de construcción", en ANSI C37.32-1996, vol., núm., págs. i-36, 1996, doi: 10.1109 / IEEESTD.1996.95627.

[3]NEMA SG-6-1995, Nema sg 61995 tablas 321114 ilustración determina [Online], Available: https://www. coursehero.com/file/p5ngkj3/NEMA-SG-6-1995-Tables-32-1-114-Illustration-Determine-the-electrical/

[4]COVENIN 2238:2000. Radiaciones No Ionizantes. [Online], Available: http://www.sencamer.gob.ve/sencamer/normas/2238-00.pdf

[5]Codigo Nacional de Seguridad en Instalaciones de Suministro de Energia Electrica y de Comuninaciones, CODELETECTRA, Codigo de Seguridad Electrica. Espacios libres mínimos para partes activas.

[6]ESP OIL Engineering Consultants, WorkShop International, "Diseno de subestaciones eléctricas", dictado por M.Sc Manuel Briceno, 2006

[7]F.Gonzalez-Longatt, Líneas De Transmisión. [Online], Available: https://fglongatt.org/OLD/Archivos/LT_1. html

[8]R. López Valverde. Historia del electromagnetismo. Ediciones IES, Pablo Picasso, 2001.

[9]P. Muné, M. Hernández-Wolpez, A. Cruz-García y RJ Jardim. (2015). “Sobre la penetración y atrapamiento del flujo magnético en superconductores Bi-2223”. Rev. Cubana de Física. Vol. 32, no. 1 pp 53

[10]C. Furió y J. Guisasola. (2001). "La enseñanza del concepto de campo eléctrico basada en un modelo de aprendizaje como investigación orientada”. Rev. Enseñanza De Las Ciencias, 19 (2), pp.319-334

[11]D. Vásquez Gonzales. (2017) “Aplicación del método cadena crítica para la mejora en construcción de cimentaciones de torres autosoportadas - caso línea de transmisión 66kV, en Sayán, Lima” Tesis de grado. Universidad César vallejo. Perú.

[12]J. Maxwell (1864). “Una teoría dinámica del campo electromagnético”. Rev. Sociedad de la realeza. Vol 155. [13]D. Strebkov. (2014) "Perspectivas de uso de tecnologías de nicola tesla en ingeniería de energía actualizada". Rev.Light \& Engineering. vol. 22 Edición 2, pp 4-14. 